\title{
Effects of Nano Silica, Micro Silica, Fly Ash and Bottom Ash on Compressive Strength of Concrete
}

\author{
Thushara Priyadarshana ${ }^{1}$, Ranjith Dissanayake ${ }^{1}$ and Priyan Mendis ${ }^{2}$ \\ 1. Department of Civil Engineering, University of Peradeniya, Peradeniya 20400, Sri Lanka \\ 2. Department of Infrastructure Engineering, University of Melbourne, Melbourne 3000, Australia
}

\begin{abstract}
In this study, SCM (supplementary cementitious materials), such as nano silica, micro silica, fly ash and bottom ash, have been evaluated for optimal level of replacement as blending material in cement and concrete. The physical and chemical properties of the above materials were first analyzed. This study focused on compressive strength of concrete with different mixes at different ages. In many cases, products made with fly ash, micro silica, nano silica and bottom ash perform better than products made without them. Test results obtained in this study indicate that up to $5 \%$ nano silica, $10 \%$ micro silica, $20 \sim 30 \%$ fly ash and $10 \%$ bottom ash could be advantageously blended with cement without adversely affecting the strength. However, optimum levels of these materials are 1 3\% nano silica, $3 \sim 8 \%$ micro silica, $10 \%$ fly ash and $5 \%$ of bottom ash when we consider the strength of concrete. All percentages are defined by weight unless otherwise mentioned.
\end{abstract}

Key words: SCM, fly ash, nano silica, micro silica, bottom ash.

\section{Introduction}

Concrete is the second most consumed material after water and it shapes the built environment around the world. According to U.S. Geological Survey, mineral commodity summaries January 2015 and the cement production in the world in 2014 is 4.18 billion metric tons [1]. Estimated concrete production in the world in 2009 was more than 25 billion metric tons according to CSI (Cement Sustainability Initiative) report [2]. Fly ash and silica fume can be used as cementious materials to enhance strength and durability properties of concrete [3-5]. These materials can be added as a last step in cement production or when the concrete is made.

The aim of this paper is to present the latest findings in the properties and application of SCM (supplementary cementitious materials) which is currently available in Sri Lanka. Sustainability is an important issue all over the world and carbon dioxide

Corresponding author: Thushara Priyadarshana, Ph.D. researcher, research fields: nano and micro materials in concrete, fly ash concrete, durability of concrete and high performance concrete. E-mail: thusharaSL@gmail.com. emission has been a serious problem in the world due to the greenhouse effect.

Today, many countries agreed to reduce the emission of $\mathrm{CO}_{2}$. Many phases of cement and concrete technology can affect sustainability. Cement and concrete industry is responsible for the production of $7 \%$ carbon dioxide of the total world $\mathrm{CO}_{2}$ emission [2]. The use of SCM, design of concrete mixtures with optimum content of cement and enhancement of concrete durability are the main issues toward sustainability in concrete industry.

According to SLSI (Sri Lanka Standards Institution) standards, cement can be produced with SCM under two categories: (1) hydraulic blended cements (fly ash/pozolana up to $35 \%$ replacement); (2) Portland limestone cements (limestone up to 20\% replacement) which are produced under SLS 1247 and SLS 1253 [6, 7], respectively. However, there are limitations of using such materials in concrete. According to European standards EN 197-1 [8], fly ash can be included in 10 cement types as main constituents and micro silica can be used in five cements types as main constituents from $6 \%$ to $35 \%$. In most of the countries, these 
materials are widely used, considering their effects of long-term durability on concrete.

SCM improve concrete properties mainly in two ways: First, it helps to generate more CSH (calcium-silicate-hydrate) in the pozzolanic reaction with $\mathrm{Ca}(\mathrm{OH})_{2}$; Second, it provides denser concrete due to better particle packing. Finally, these concretes would be high-strength and durable [9]. Limitations are given in most of the standards for different types of SCM based on their cementing properties.

\section{Experimental Program}

Chemical compositions of cement and SCM were analysed using XRF (X-ray fluorescence) analyser, according to EN 196-2 standard. Percentages of silicon dioxide $\left(\mathrm{SiO}_{2}\right)$, aluminum oxide $\left(\mathrm{Al}_{2} \mathrm{O}_{3}\right)$, ferric oxide $\left(\mathrm{Fe}_{2} \mathrm{O}_{3}\right)$, calcium oxide $(\mathrm{CaO})$, magnesium oxide $(\mathrm{MgO})$, sulfur trioxide $\left(\mathrm{SO}_{3}\right)$, sodium oxide $\left(\mathrm{Na}_{2} \mathrm{O}\right)$, potassium oxide $\left(\mathrm{K}_{2} \mathrm{O}\right)$, chloride content $(\mathrm{Cl})$ and LOI (loss on ignition) are measured individually.

Concrete cube specimens of $150 \mathrm{~mm} \times 150 \mathrm{~mm} \times$ $150 \mathrm{~mm}$ were prepared according to European standard. These specimens were cast from Concrete Grade 35 and widely used in industrial segment with different percentage replacement of cement with SCM, as described from Test $\mathrm{C} 1$ to Test $\mathrm{C} 20$ in Table 1. Compressive strengths of concrete cubes were tested at 7 days, 28 days, 60 days and 90 days. Altogether 240 specimens were cast and tested for the compressive strengths according to European standard BSEN 12390-3.

In Test $\mathrm{C} 1$, pure OPC (ordinary Portland cement) was used in concrete mix: $64.2 \mathrm{C}_{3} \mathrm{~S}, 10.4 \mathrm{C}_{2} \mathrm{~S}, 7.2$ $\mathrm{C}_{3} \mathrm{~A}$ and $9.9 \mathrm{C}_{4} \mathrm{AF}$ with fineness of $3,450 \mathrm{~cm}^{2} / \mathrm{g}$.

In Tests $\mathrm{C} 2-\mathrm{C} 6$, cement was replaced by weight $1 \%$, $3 \%, 5 \%, 10 \%$ and $20 \%$ of micro silica $(\mathrm{mS})$, which was bought from local supplier. Silica fume has average particle size of $150 \mu \mathrm{m}$. The maximum percentage of possible silica fume for a workable mix was $20 \%$ by weight with maximum recommended amount of super plasticizers. Most of the literatures recommended $5 \sim 8 \%$ micro silica in concrete. Some standards recommend maximum ceiling of micro silica as $10 \%$ by weight.

Table 1 Concrete mixture proportions.

\begin{tabular}{|c|c|c|c|c|c|c|c|c|c|}
\hline Concrete test & $\begin{array}{l}\text { Cement OPC } \\
(\mathrm{kg})\end{array}$ & $\begin{array}{l}\text { Sand } \\
(\mathrm{kg})\end{array}$ & $\begin{array}{l}\text { Coarse } \\
\text { aggregates } \\
(\mathrm{kg})\end{array}$ & $\begin{array}{l}\text { Water } \\
\text { (L) }\end{array}$ & $\begin{array}{l}\text { Chemical } \\
\text { admixture } \\
(\mathrm{mL})\end{array}$ & $\begin{array}{l}\text { Fly ash } \\
(\mathrm{kg})\end{array}$ & $\begin{array}{l}\text { Micro silica } \\
(\mathrm{kg})\end{array}$ & $\begin{array}{l}\text { Nano silica } \\
(\mathrm{kg})\end{array}$ & $\begin{array}{l}\text { Bottom ash } \\
(\mathrm{kg})\end{array}$ \\
\hline $\mathrm{C} 1$ (OPC) & 435.00 & 774 & 1,026 & 174 & 4,350 & - & - & - & - \\
\hline $\mathrm{C} 2(\mathrm{OPC}+1 \% \mathrm{mS})$ & 430.65 & 774 & 1,026 & 174 & 4,350 & - & 4.35 & - & - \\
\hline $\mathrm{C} 3(\mathrm{OPC}+3 \% \mathrm{mS})$ & 421.95 & 774 & 1,026 & 174 & 4,350 & - & 13.05 & - & - \\
\hline $\mathrm{C} 4(\mathrm{OPC}+5 \% \mathrm{mS})$ & 413.25 & 774 & 1,026 & 174 & 4,350 & - & 21.75 & - & - \\
\hline $\mathrm{C} 5(\mathrm{OPC}+10 \% \mathrm{mS})$ & 391.50 & 774 & 1,026 & 174 & 4,350 & - & 43.50 & - & - \\
\hline $\mathrm{C} 6(\mathrm{OPC}+20 \% \mathrm{mS})$ & 348.00 & 774 & 1,026 & 174 & 4,350 & - & 87.00 & - & - \\
\hline $\mathrm{C} 7(\mathrm{OPC}+1 \% \mathrm{nS})$ & 430.65 & 774 & 1,026 & 174 & 4,350 & - & - & 4.35 & - \\
\hline $\mathrm{C} 8(\mathrm{OPC}+3 \% \mathrm{nS})$ & 421.95 & 774 & 1,026 & 174 & 4,350 & - & - & 13.05 & - \\
\hline $\mathrm{C} 9(\mathrm{OPC}+5 \% \mathrm{nS})$ & 413.25 & 774 & 1,026 & 174 & 4,350 & - & - & 21.75 & - \\
\hline $\mathrm{C} 10(\mathrm{OPC}+5 \% \mathrm{FA})$ & 413.25 & 774 & 1,026 & 174 & 4,350 & 21.75 & - & - & - \\
\hline $\mathrm{C} 11(\mathrm{OPC}+10 \% \mathrm{FA})$ & 391.50 & 774 & 1,026 & 174 & 4,350 & 43.50 & - & - & - \\
\hline $\mathrm{C} 12(\mathrm{OPC}+20 \% \mathrm{FA})$ & 348.00 & 774 & 1,026 & 174 & 4,350 & 87.00 & - & - & - \\
\hline $\mathrm{C} 13(\mathrm{OPC}+30 \% \mathrm{FA})$ & 304.50 & 774 & 1,026 & 174 & 4,350 & 130.50 & - & - & - \\
\hline $\mathrm{C} 14(\mathrm{OPC}+40 \% \mathrm{FA})$ & 261.00 & 774 & 1,026 & 174 & 4,350 & 174.00 & - & - & - \\
\hline $\mathrm{C} 15(\mathrm{OPC}+50 \% \mathrm{FA})$ & 217.50 & 774 & 1,026 & 174 & 4,350 & 217.50 & - & - & - \\
\hline $\mathrm{C} 16(\mathrm{OPC}+5 \% \mathrm{BA})$ & 413.25 & 774 & 1,026 & 174 & 4,350 & - & - & - & 21.75 \\
\hline $\mathrm{C} 17(\mathrm{OPC}+10 \% \mathrm{BA})$ & 391.50 & 774 & 1,026 & 174 & 4,350 & - & - & - & 43.50 \\
\hline $\mathrm{C} 18(\mathrm{OPC}+20 \% \mathrm{BA})$ & 348.00 & 774 & 1,026 & 174 & 4,350 & - & - & - & 87.00 \\
\hline $\mathrm{C} 19(\mathrm{OPC}+30 \% \mathrm{BA})$ & 304.50 & 774 & 1,026 & 174 & 4,350 & - & - & - & 130.50 \\
\hline $\mathrm{C} 20(\mathrm{OPC}+40 \% \mathrm{BA})$ & 261.00 & 774 & 1,026 & 174 & 4,350 & - & - & - & 174.00 \\
\hline
\end{tabular}


In Tests C7-C9, cement was replaced by weight $1 \%$, $3 \%$ and $5 \%$ of nano silica $(\mathrm{nS})$, having average particle size of $10 \mathrm{~nm}$, bought from Chinese supplier. The limitation of nano silica replacement was mainly decided on concrete properties and high price of materials, which is not worth to replace higher amount of cement with nano silica. In most of the literature, it is recommended using $2 \sim 3 \%$ by weight of nano silica in concrete.

In Tests $\mathrm{C} 10-\mathrm{C} 15$, cement was replaced by weight $5 \%, 10 \%, 20 \%, 30 \%, 40 \%$ and $50 \%$ of fly ash (FA), bought from Norochcholai Power Plant. It showed that fly ash can be easily replaced up to $50 \%$ by weight of cement without workability issues even with half of the recommended chemical admixture dosage $(1,000 \mathrm{~mL}$ of super plasticizer $/ 100 \mathrm{~kg}$ of cement). Even though our local standards limit fly ash usage up to $35 \%$ by weight, it was checked up to $50 \%$ by weight replacement.

In Tests C16-C20, cement was replaced by weight $5 \%, 10 \%, 20 \%, 30 \%$ and $40 \%$ of bottom ash (BA).

In all these tests, amounts of coarse aggregates, fine aggregates and water were kept constant and admixtures are mostly used constant except in two tests (silica fume replacement by weight of $10 \%$ and $20 \%$ ). The reason for increasing admixtures (double the dosage to $2,000 \mathrm{~mL} / 100 \mathrm{~kg}$ of cement) was due to very low workability of concrete mix when used with cement replacement above $10 \%$ by weight of silica fume.

\section{Results and Discussion}

According to chemical analysis given in Table 2, it showed that fly ash can be categorized as Class F according to general standards [4]. This fly ash was low in lime 5.55\% (under 15\%), and contained a greater combination of silica, alumina and iron up to $84.34 \%$ (greater than 70\%). Nano silica and micro silica have purity of $99.59 \%$ and $98.93 \%$. Bottom ash contains a greater combination of silica, alumina and iron up to $69.78 \%$.

As shown in Table 3, natural river sand with below sieve analysis was done according to BS 882:1992, while clay content is $1 \%$ (passed through $75 \mu \mathrm{m}$ sieve) and reactive clay content is $0.69 \mathrm{mg} / \mathrm{g}$ measured according to methylene blue test which was used for all tests [10].

As shown in Table 4, crushed granite aggregated with below sieve analysis was done according to BS 882:1992, while AIV (aggregate impact value) of $19.8 \%$ was used for all tests [10].

Compressive strengths of Grade-35 concrete mixed according to experimental program are shown in Tables 5-8 and Figs. 1-7.

Table 2 Chemical compositions of cement and SCM.

\begin{tabular}{llllllllll}
\hline Materials & $\mathrm{SiO}_{2}(\%)$ & $\mathrm{Al}_{2} \mathrm{O}_{3}(\%)$ & $\mathrm{Fe}_{2} \mathrm{O}_{3}(\%)$ & $\mathrm{CaO}(\%)$ & $\mathrm{MgO}(\%)$ & $\mathrm{SO}_{3}(\%)$ & $\mathrm{K}_{2} \mathrm{O}(\%)$ & $\mathrm{Na}_{2} \mathrm{O}(\%)$ & $\mathrm{Cl}(\%)$ \\
\hline Cement & 20.38 & 4.79 & 3.26 & 64.40 & 0.98 & 2.21 & 0.04 & - & 0.01 \\
Micro silica & 98.93 & - & 0.31 & - & 0.17 & - & - & 0.57 & - \\
Nano silica & 99.59 & - & 0.33 & - & 0.06 & - & - & - & - \\
Fly ash & 52.03 & 32.31 & 7.04 & 5.55 & 1.30 & 0.07 & 0.68 & 1.00 & - \\
Bottom ash & 46.09 & 23.69 & 5.81 & 7.04 & 1.18 & - & 1.15 & 0.69 & - \\
\hline
\end{tabular}

Table 3 Properties of fine aggregates (sand).

\begin{tabular}{llllllll}
\hline Sieve size (mm) & 10 & 5.0 & 2.36 & 1.18 & 0.60 & 0.30 & 0.15 \\
\hline Cumulative percentage passed (\%) & 100.00 & 95.40 & 88.40 & 73.40 & 48.80 & 21.00 & 4.60 \\
\hline
\end{tabular}

Table 4 Properties of corse aggregates.

\begin{tabular}{llllll}
\hline Sieve size (mm) & 37.5 & 20.0 & 14.0 & 10.0 & 5.0 \\
\hline Cumulative percentage passed (\%) & 100.00 & 92.04 & 33.72 & 6.82 & 0.86 \\
\hline
\end{tabular}


Table 5 Strength of concrete with micro silica.

\begin{tabular}{lllll}
\hline $\begin{array}{l}\text { Compressive strength } \\
\text { (MPa) }\end{array}$ & 7 days & 28 days & 60 days & 90 days \\
\hline $\mathrm{C} 1(\mathrm{OPC})$ & 46.3 & 57.7 & 59.3 & 62.1 \\
$\mathrm{C} 2(\mathrm{OPC}+1 \% \mathrm{mS})$ & 48.7 & 57.4 & 60.2 & 61.7 \\
$\mathrm{C} 3(\mathrm{OPC}+3 \% \mathrm{mS})$ & 50.1 & 62.2 & 63.0 & 63.9 \\
$\mathrm{C} 4(\mathrm{OPC}+5 \% \mathrm{mS})$ & 48.9 & 62.1 & 63.2 & 65.1 \\
$\mathrm{C} 5(\mathrm{OPC}+10 \% \mathrm{mS})$ & 52.6 & 57.7 & 60.4 & 61.6 \\
$\mathrm{C} 6(\mathrm{OPC}+20 \% \mathrm{mS})$ & 49.3 & 54.0 & 55.4 & 58.7 \\
\hline
\end{tabular}

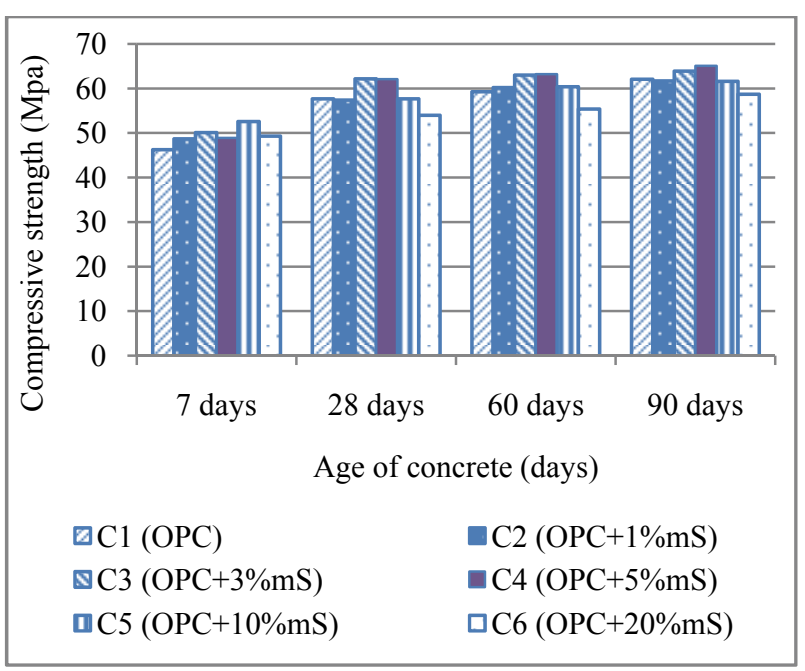

Fig. 1 Strength of concrete with micro silica.

Table 6 Strength of concrete with nano silica.

\begin{tabular}{lclll}
\hline $\begin{array}{l}\text { Compressive strength } \\
\text { (MPa) }\end{array}$ & 7 days & 28 days & 60 days & 90 days \\
\hline C1 $(\mathrm{OPC})$ & - & 57.7 & 59.3 & 62.1 \\
$\mathrm{C} 7(\mathrm{OPC}+1 \% \mathrm{nS})$ & 45.3 & 60.8 & 61.7 & 63.0 \\
$\mathrm{C} 8(\mathrm{OPC}+3 \% \mathrm{nS})$ & 44.6 & 57.9 & 60.7 & 62.6 \\
$\mathrm{C} 9(\mathrm{OPC}+5 \% \mathrm{nS})$ & 41.4 & 54.6 & 59.5 & 63.8 \\
\hline
\end{tabular}

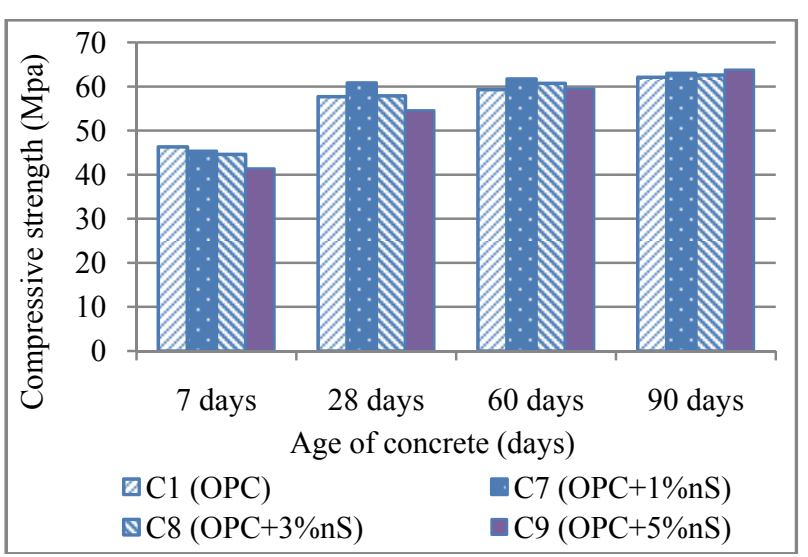

Fig. 2 Strength of concrete with nano silica.

Table 5 and Figs. 1, 5-7 show that cement can be easily replaced by micro silica when it is up to $10 \%$ without losing strength of concrete at all ages. The best amount of micro silica in concrete would be 3 8\%. These values are very much aligned with the amount of micro silica used in all the concrete mix designs of world tallest building, Burj Khalifa in Dubai, which is from $5 \%$ to $9 \%$ by weight ( $15 \mathrm{~kg}$ to $50 \mathrm{~kg}$ for cubic meter of concrete) [11]. Main issue when dealing with micro silica is losing workability of concrete mix at higher percentages of micro silica. High range super plasticizers are always recommending using with micro silica.

Table 6 and Figs. 2, 5-7 show that cement can be replaced by nano silica when it is up to $5 \%$ without losing strength of concrete at late ages (60 days and 90 days). However, early strength of concrete is badly affected by nano silica in all cases. The best amount of nano silica in concrete would be $1 \sim 3 \%$ by considering its cost and optimum benefits. It has been observed by other researchers that the compressive strength of concrete at 7 days and 28 days are at maximum with $10 \%$ micro silica and $2 \%$ nano silica combination and compressive strength of concrete with $2 \%$ nano silica is nearly same as with $5 \%$ micro silica [12].

Table 7 and Figs 3, 5-7 show that cement can be replaced by fly ash when it is up to $20 \sim 30 \%$ without losing strength of concrete at late ages (60 days and 90 days). However, early strength of concrete is affected by fly ash when it uses more than $20 \%$. The best amount of fly ash in concrete would be $10 \%$ by considering optimum benefits towards strength. Main benefits of fly ash are workability of concrete mix even at very high percentages. These are really useful for

Table 7 Strength of concrete with fly ash.

\begin{tabular}{lllll}
\hline $\begin{array}{l}\text { Compressive strength } \\
\text { (MPa) }\end{array}$ & 7 days & 28 days & 60 days & 90 days \\
\hline C1 (OPC) & 46.3 & 57.7 & 59.3 & 62.1 \\
C10 (OPC + 5\%FA) & 46.9 & 58.6 & 62.7 & 65.3 \\
C11 (OPC + 10\%FA) & 53.0 & 61.4 & 64.1 & 66.5 \\
C12 (OPC + 20\%FA) & 46.5 & 58.6 & 62.4 & 65.4 \\
C13 (OPC + 30\%FA) & 40.9 & 51.9 & 57.8 & 61.9 \\
C14 (OPC + 40\%FA) & 35.3 & 50.3 & 56.2 & 60.0 \\
C15 (OPC + 50\%FA) & 32.4 & 45.5 & 54.0 & 58.2 \\
\hline
\end{tabular}




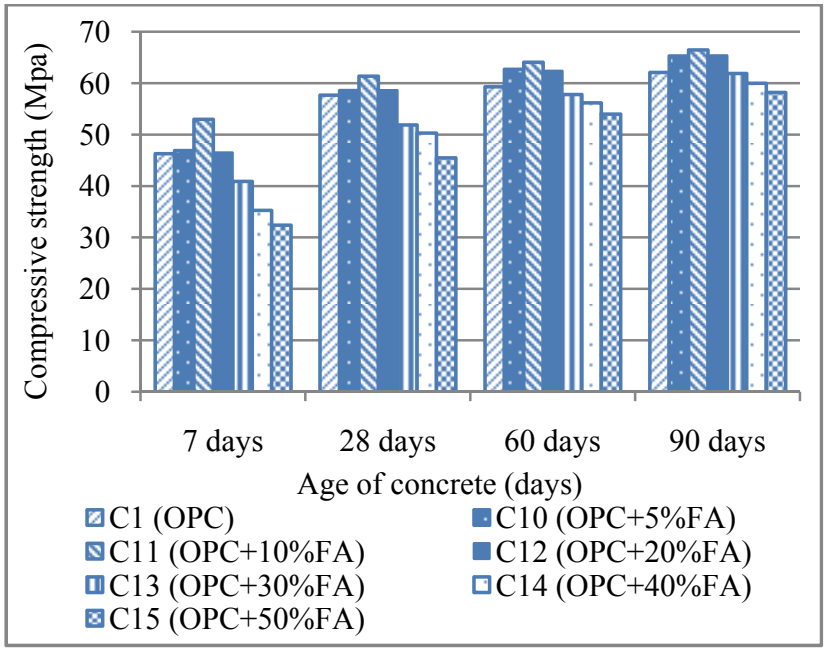

Fig. 3 Strength of concrete with fly ash.

Table 8 Strength of concrete with bottom ash.

\begin{tabular}{lllll}
\hline $\begin{array}{l}\text { Compressive strength } \\
\text { (MPa) }\end{array}$ & 7 days & 28 days & 60 days & 90 days \\
\hline $\mathrm{C} 1(\mathrm{OPC})$ & 46.3 & 57.7 & 59.3 & 62.1 \\
$\mathrm{C} 16(\mathrm{OPC}+5 \% \mathrm{BA})$ & 48.4 & 58.8 & 63.0 & 68.7 \\
$\mathrm{C} 17(\mathrm{OPC}+10 \% \mathrm{BA})$ & 46.2 & 57.6 & 62.6 & 65.9 \\
$\mathrm{C} 18(\mathrm{OPC}+20 \% \mathrm{BA})$ & 45.3 & 56.2 & 62.7 & 66.5 \\
$\mathrm{C} 19(\mathrm{OPC}+30 \% \mathrm{BA})$ & 42.5 & 55.0 & 60.6 & 63.4 \\
$\mathrm{C} 20(\mathrm{OPC}+40 \% \mathrm{BA})$ & 34.5 & 49.3 & 54.3 & 59.2 \\
\hline
\end{tabular}

concrete which is to be pumped for longer distances, especially for high rise structures. These values are very much aligned with amount of fly ash used in all the concrete mix designs of world tallest building, Burj Khalifa in Dubai, which is from $12 \%$ to $24 \%$ by weight (60 kg to $112 \mathrm{~kg}$ for cubic meter of concrete) [11].

It is discussed in some researches that strength of cement pastes with $5 \sim 10 \%$ by weight of fly ash increases by $39.3 \%$ and $35.7 \%$ at $450{ }^{\circ} \mathrm{C}$ [13].

In other researches, researchers proved that the composite cement pastes made from $10 \%$ of micro silica and $10 \%$ fly ash have good fire resistance in comparison with cement pastes made from only SF-pozzolanic cement pastes up to $450{ }^{\circ} \mathrm{C}$ [13]. The percentage increase in compressive strength of ternary blended concrete ( $5 \%$ micro silica $+15 \%$ fly ash) at the age of 90 days and 180 days with its 28 -day strength is observed to be 10 30\% [14].

Table 8 and Figs 4-7 show that cement can be replaced by bottom ash up to $10 \%$ without losing strength of concrete at late ages (60 days and 90 days). However, early strength of concrete is badly affected by bottom ash when it uses more than 5\%. The best amount of bottom ash in concrete would be less than $5 \%$ by considering optimum benefits towards strength. Most

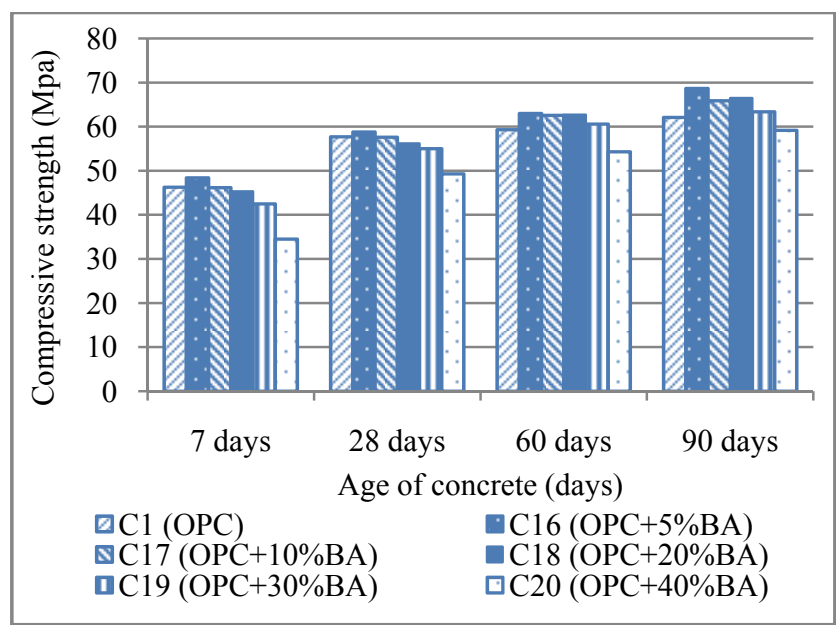

Fig. 4 Strength of concrete with bottom ash.

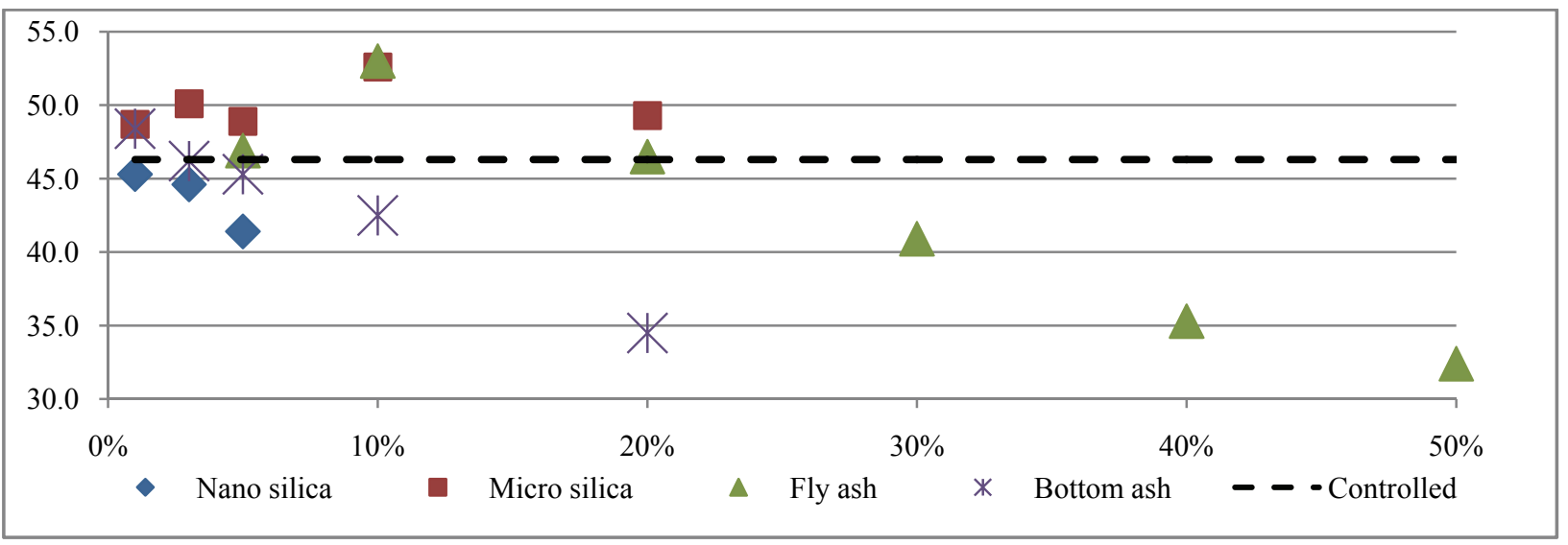

Fig. 5 Compressive strength of concrete with nano silica, micro silica, fly ash and bottom ash at 7 days. 


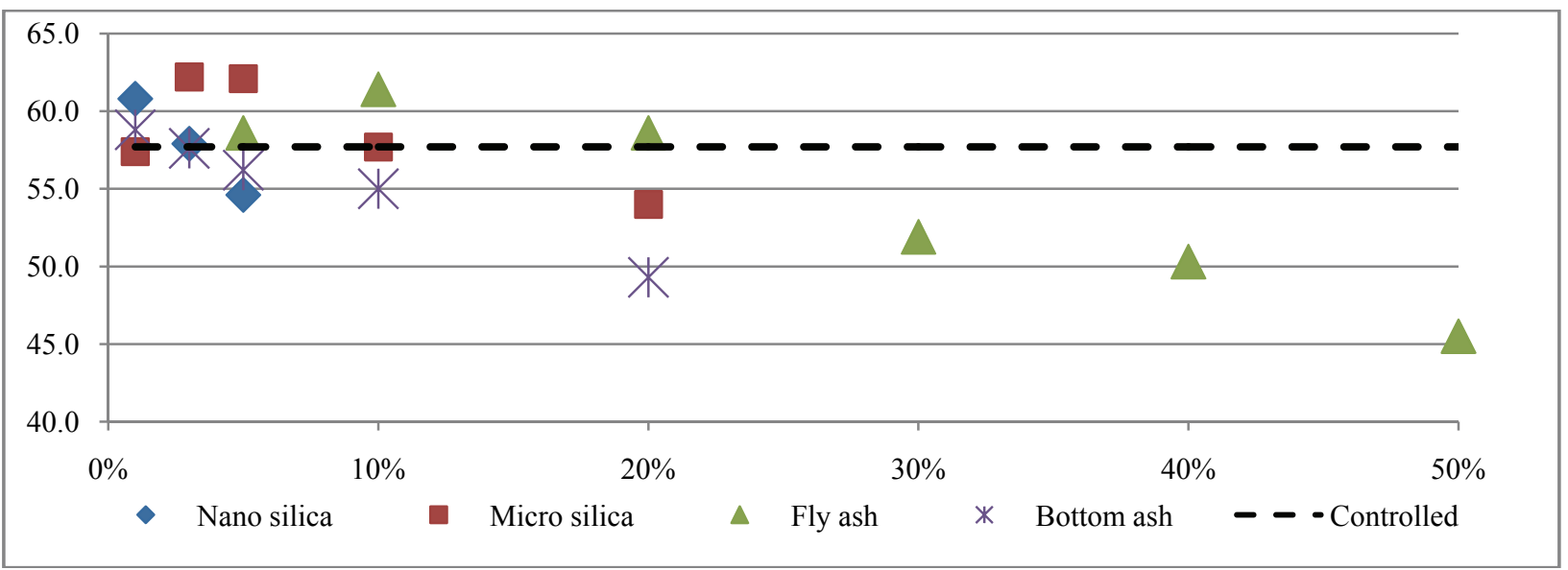

Fig. 6 Compressive strength of concrete with nano silica, micro silica, fly ash and bottom ash at 28 days.

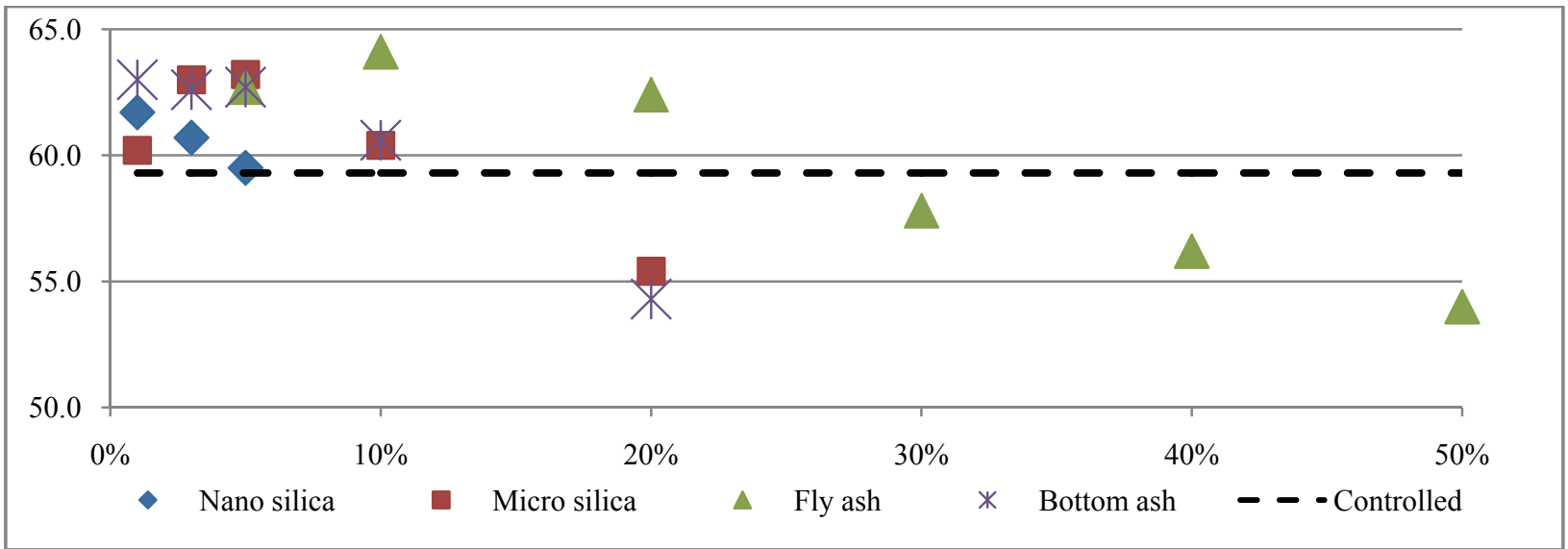

Fig. 7 Compressive strength of concrete with nano silica, micro silica, fly ash and bottom ash at 60 days.

literature discussed and recommended bottom ash as a replacement for fine aggregates. However, this study proved that bottom ash has cementitious properties and can be used as cement replacement material as well.

\section{Conclusions}

Test results obtained in this study indicate that up to $5 \%$ nano silica, $10 \%$ micro silica, $20 \sim 30 \%$ fly ash and $5 \%$ bottom ash could be advantageously blended with cement without adversely affecting the strength. However, optimum levels of these materials are 1 3\% nano silica, $3 \sim 8 \%$ of micro silica, $10 \%$ fly ash and $5 \%$ bottom ash. However, when these materials are inter-ground with clinker to produce blended cement, they can give better results than usual mixing at ready mix plant or mixing at cement plant.

The maximum limit of fly ash can be used in cement in Sri Lanka is 35\%. However, a higher amount of fly ash can be used in concrete if a turnery blend, like nano silica or micro silica, is added into the system.

Micro silica used in all the concrete mix designs of world tallest building, Burj Khalifa in Dubai, is from $5 \%$ to $9 \%$ by weight. Fly ash used in all the concrete mix designs of world tallest building, Burj Khalifa in Dubai, is from $12 \%$ to $24 \%$ by weight.

In Sri Lanka, in most of the projects, fly ash are used in the range of $20 \sim 25 \%$. Fly ash blended cement produced by local cement manufacturer, Holcim (Lanka) Limited (Holcim Extra) contains 25\% fly ash and fly ash is inter-ground at the cement plant to get better performance. Micro silica with fly ash is used in most of the high rise building projects in the world to get higher strength and extended durability. However, nano silica is still new to construction industry due to 
its availability and cost.

It is always recommended to optimize mix designs either with blended cement or with cement replacement materials, such as fly ash (with/without micro silica or nano silica), to get highest performance with the concrete. It is proved that Grade- 80 concrete can be achieved even low cement content (400 kg) if $100 \mathrm{~kg}$ fly ash (18\%) and $50 \mathrm{~kg}$ micro silica (9\%) are mixed, as shown in the Burj Dubai example. So, it is not recommended to just increase the cement content to enhance strength and other properties of concrete. There will always be a better option with blended cement or blended materials with ordinary Portland cement.

\section{References}

[1] Jewell, S., and Kimball, S. 2015. Mineral Commodity Summaries 2015. Washington D.C.: U.S. Geological Survey, U.S. Department of Interior.

[2] ACI (American Concrete Institute). 2009. "The Cement Sustainability Initiative." World Business Council for Sustainable Development. Accessed September 8, 2015. http://www.wbcsdcement.org/pdf/CSI\%20GNR\%20Repo rt $\% 20$ final $\% 2018 \% 206 \% 2009$.pdf.

[3] CIVL 1101-Class Presentations and Notes. 2015. "PCA (Portland Cement Association) Manual-Fly Ash, Slag, Silica Fume, and Natural Pozzolans." Chapter 3. University of Memphis. Accessed September 9, 2015. http://www.ce.memphis.edu/1101/notes/concrete/PCA_m anual/Chap03.pdf.

[4] Thomas, M. 2007. Optimizing the Use of Fly Ash in Concrete. Skokie: PCA (Portland Cement Association).

[5] ASTM International. 2015. "Standard Specification for Coal Fly Ash and Raw or Calcined Natural Pozzolan for
Use in Concrete." In ASTM C618-15. West Conshohocken: ASTM International.

[6] Sri Lanka Standards Institute. "Standards Specification for Blended Hydraulic Cements (1st Revision)." In Sri Lanka Standards 1247-2008. Colombo: Sri Lanka Standards Institute.

[7] Sri Lanka Standards Institute. "Standards Specification for Portland Limestone Cements (1st Revision)." In Sri Lanka Standards 1253-2008. Colombo: Sri Lanka Standards Institute.

[8] European Standard EN 197-1. 2011. Cement-Part 1: Composition, Specifications and Conformity Criteria for Common Cements. Brussels: British Standards Institution.

[9] Neville, A. M. 1995. Properties of Concrete. Delhi: Pearson Education (Singapore) Pte. Ltd.

[10] European Standards BSEN 12620:2002+A1. 2008. Aggregates for Concrete. Brussels: British Standards Institution.

[11] Wickline, T. 2008. "Summary of Concrete Mix Design for Burj Dubai Tower." Dubai-tower.blogspot.com. Accessed September 2015. http://dubaitower.blogspot.com/2008/08/summary-of-con crete-mix-design-for-burj.html.

[12] Sai, S., Swami, B. L., Saikiran, B., and Saratri, M. V. 2013. "Comparative Studies on High Strength Concrete Mixes Using Micro Silica and Nano Silica." IJETR (International Journal of Engineering and Technical Research) 1 (7): 60-5.

[13] Heikal, M., Didamony, H. E., Sokkary, T. M., and Ahmed, I. A. 2013. "Behaviour of Composite Cement Pastes Containing Micro Silica and Fly Ash at Elevated Temperature." Construction and Building Materials 38: $1180-90$

[14] Audinarayana, D., Sarika, P., Seshadri, S. T., Ravo, S., and Apparao, P. S. 2013. "Studies on Compressive Strength of Ternary Blended Concretes at Different Water Binder Ratios." AJER (American Journal of Engineering Research) 2 (9): 37-45. 